Egypt. J. of Nutrition and Health Vol. 15 No. 2 July (2020)

\title{
The Bioactive Effects of Sesame Seeds on Atherosclerosis and Inflammation in Rats.
}

\author{
Hoda S. Ibrahim, Lamiaa A. Ahmed and Asmaa A. Mohammed \\ Nutrition and Food Science Dep., Faculty of Home Economics \\ Helwan University, Cairo - Egypt.
}

\begin{abstract}
This study was carried out to investigate the bioactive effects of sesame seeds against inflammation and atherosclerotic rats. Adult male Sprague- Dawley strain rats $(n=72)$ were divided into two main groups, the first main group $(n=9)$ was fed on basal diet as a negative control group. Atherosclerosis was induced in the second main group $(n=63)$ which was assigned to groups $2-8$. Group 2 was positive control group; the others were treated with raw, roasted and fermented sesame seeds respectively each at two levels of intake (100 and $150 \mathrm{gm} / \mathrm{kg} \mathrm{diet})$. At the end of the experimental period (8 weeks), blood samples were collected for assessing liver and kidney functions, serum vitamin $\mathrm{E}$ and serum oxidative stress markers.Pedal inflammation was induced by $0.1 \mathrm{ml}$ formalin (4\%) in atherosclerotic rats and paw's thickness was recoded. Liver from all rats were collected for histological studies.Results revealed that supplementation with forms of sesame seeds improved atherogenic index as well as caused an improvement in AST enzyme at the tested levels of intake compared with the positive control group as well as the activity of oxidative enzymes in the atherosclerotic rats, resulted in marked increase in SOD concentrations compared with positive control group. Results showed that the addition of sesame seeds led to a significant improvement in pedal after 3, 6 hrs., 1 day, 2 day, 4 day, and 6 days of inducing inflammation .In view of the positive effect of raw, roasted and fermented sesame seeds on most of the studied parameters, the present study recommends increasing the consumption of sesame seeds in the different forms. Nutrition education programs are needed to clarify the importance of sesame seeds in reducing inflammation and combating complication of atherosclerosis. Further studies are required to evaluate the health benefits of consuming fermented sesame seeds.
\end{abstract}

Key words: raw sesame seeds - roasted sesame seeds - fermented sesame seeds - atherosclerosis pedal inflammation - rats - histology.

\section{Introduction}

Sesame (Pedaliaceae family, Sesamumindicum L.) is one of the most important oil seed crops and is widely cultivated in tropical and subtropical areas such as Myanmar, India, China, and Africa (Yushiroet al., 2018) Recently it has attracted research attention for its medicinal properties and physiological effects such as its oil quality, sterols, and antioxidative agents i.e., methylene dioxyphenyl compounds, sesamin, sesamolin, and tocopherols that act as nutraceuticals and impart resistance to oil against oxidative deterioration (NitiPathaket al., 2019).

Enhancement of the nutritional and medicinal quality of sesame seeds may be anticipated through processing (such as roasting and fermentation) prior to consumption. These processes cause 


\section{Hoda S. Ibrahim, et al}

important physical, chemical, structural and sensorial changes. In the light of this, Hassan, (2012) reported that roasted sesame seeds gave the most desirable quality of raw sesame seeds with respect to phenolic content and fatty acids composition. In addition, Rizkiet al., (2016) stated that sesame oil extracted from roasted sesame seeds was considered more anti oxidative and with better sensory and nutritional properties than unroasted sesame oil.

Antioxidants such as vitamin $\mathrm{E}$ are known to protect LDL-cholesterol against oxidative modification (Niki, 2011). In addition, the consumption of poly unsaturated fatty acids PUFA- and mono unsaturated fatty acids (MUFA) -rich oils may help decrease the fractions of circulating lipid levels, as well as the risk of cardiovascular diseases (CVD) (Mozaffarian et al., 2010).

Inflammation is a body's natural response against harmful pathogen and stimuli that occurs in two stages namely, acute and chronic inflammation. Acute inflammation is a part of innate immunity initiated by the immune cells that persists only for a short time. However, if the inflammation continued, the second stage of inflammation called chronic inflammation commences which instigates various kinds of chronic diseases, including arthritis, cancer, cardiovascular diseases, diabetes, and neurological diseases (Ajaikumaret al., 2018).

The aim of the present study was to evaluate the bioactive effects of raw sesame seeds and other two treatments on atherosclerosis and inflammation in rats.

\section{Materials and Methods}

\section{Materials}

- Chemicals: Cholesterol (white crystalline powder), casein, vitamins, minerals, cellulose, choline chloride and formalin were obtained from Elgomhoria Company for chemical industries, Cairo, Egypt.

- White sesame seeds (Pedaliaceae family, Sesamumindicum L.), were purchased from the Agricultural Research Center, Giza, Egypt. Corn starch and corn oil were obtained from the local market, Cairo, Egypt.

- Animals: Adult male albino rats of Sprague-Dawely strain weighing $120-130 \mathrm{~g}$ were obtained from laboratory animal colony, Ministry of Health and Population, Helwan, Cairo, Egypt.

Methods:

Preparation of raw, roasted and fermented sesame seeds:

White sesame seeds (Pedaliaceae family, Sesamumindicum L.), were cleaned manually to remove dust, stones and any foreign material.

Raw:Seeds were milled (Wiley mill, 30 meshes) and were stored in a sealed clean glass container at room temperature $\left(25^{\circ} \mathrm{C}\right)$ to preserve the quality of sesame seeds till use.

Roasting: Raw Sesame seeds were roasted by putting a thin layer of raw seeds on a tray in preheated oven at $160^{\circ} \mathrm{C}$ for about $15 \mathrm{~min}$. till the seeds start getting some light golden color as described by (Hama, 2017).

Fermentation:

Fermented sesame seeds were prepared by cooking raw sesame seeds in boiling water at $100^{\circ} \mathrm{c}(1: 1)$ for $6 \mathrm{~h}$. The cooked seeds were placed in a plastic container with a tight lid and sealed. The 


\section{Egypt. J. of Nutrition and Health Vol. 15 No. 2 July (2020)}

samples were allowed to ferment in drying oven (GENTI) cell model at $35 \pm 2^{\circ} \mathrm{C}$ for 7 days and oven dried at $105^{\circ} \mathrm{C}$ for $12 \mathrm{~h}$. to bring an end to fermentation. Fermented seasame seeds were stored in a sealed clean glass container (Makinde and Akinoso, 2014).

\section{Induction of Atherosclerosis:}

The used atherogenic diet containing cholesterol, cholicacide, anhydrous milk fat, casein, mineral \& vitamin mix, sucrose, corn starch and cellulose was prepared according to Teklad Custom Diet, (2015). After acclimatization period for 7 days with rats fed on AIN-93M basal diet,random blood samples were taken weekly from the eyes using capillary tubes to analyze total cholesterol and HDL-C in order to calculate the atherogenic index $(\mathrm{Al})$ by the equation: $\mathrm{Al}=\mathrm{TC}-(\mathrm{HDL}-\mathrm{C}) \div(\mathrm{HDL}-\mathrm{C})$ according to Hanglundet al., (1991). When the calculation of the atherogenic index was confirmed, the atherosclerosistic rats were assigned to groups 2-8 (9 rats each).

\section{Experimental Animals:}

Seventy two adult male albino rats were adapted for one week on AIN-93M basal diet (Reeves et al., 1993). The present experiment was done in the animal house, Agricultural Research Center, Giza, Egypt. Animals were housed in a normal healthy condition. Rats received water and diet ad libitum. The room was lighted on a daily photo period of about $12 \mathrm{~h}$ light dark cycles.

After this week, rats were divided into two main groups as follows: The first main group $(n=9)$ was kept as a control negative group, the second main group $(n=63)$ was fed atherogenic diet to induce atherosclerosis according to Teklad Custom Diet, (2015).After insuring induction of atherogenicity, the atherosclerotic rats were assigned to groups 2-8 as follows:

Group1: negative control, fed on basal diet

Group2:atherosclerotic rats,fed on basal diet (positive control)

Group3:atherosclerotic rats, fed on basal diet $+100 \mathrm{gm} / \mathrm{kg}$ diet raw sesame seeds.

Group4: atherosclerotic rats, fed on basal diet $+150 \mathrm{gm} / \mathrm{kg}$ diet raw sesame seeds.

Group5: atherosclerotic rats, fed on basal diet $+100 \mathrm{gm} / \mathrm{kg}$ diet roasted sesame seeds.

Group6: atherosclerotic rats, fed on basal diet $+150 \mathrm{gm} / \mathrm{kg}$ diet roasted sesame seeds.

Group7: atherosclerotic rats, fed on basal diet $+100 \mathrm{gm} / \mathrm{kg}$ diet fermented sesame seeds.

Group8: atherosclerotic rats, fed on basal diet $+150 \mathrm{gm} / \mathrm{kg}$ diet fermented sesame seeds.

The whole experimental period was 8 weeks.

\section{Anti-inflammatory examination:}

At the last week of the feeding trial with sesame seeds, three rats were selected from each of the tested groups and rats 'paw were injected by $0.1 \mathrm{ml}$ formalin (4\%) to induce inflammation The changes in paw thickness after 3, 6 hrs, 1 day, 2 day, 4 day, and 6 day were measured using skin caliber. The anti-inflammatory effect was assessed by reduction in the thickness of rats 'paws according to Northover and Subramanian, (1962)..

\section{Blood samples and tissue collection:}

At the end of the experimental period, rats were fasted for 12 h., anesthetized by diethyl ether before scarifying. Blood samples were centrifuged and serum were obtained then stored at $-20^{\circ} \mathrm{C}$ in a clean well stopped vial until analysis. Alanine aminotransferase enzyme, aspartate aminotransferase, urea, creatinine, vitamin E, malondialdehyde and superoxide dismutase were determined in serum.

Organ such as livers were removed immediately after sacrificing, excised, rinsed, blotted dry with tissue paper, weighed and kept in formalin solution (10\%) for histological examination. 


\section{Hoda S. Ibrahim, et al}

\section{Biochemical Analysis:}

The biochemical analysis was carried out at Animal Health Research Institute (AHRI), Agriculture Research Center-Cairo, Egypt. Alanine aminotransferase enzyme and aspartate aminotransferase activities were measured according to method described by Sherwin, (1984).Urea was determined according to the method described by Chaneyand Marbach, (1962). Creatinine was determined according to the method described by Henry, (1964). Serum vitamin E was determined by the method described by Tietz, (1999). Serum malondialdehyde determination was performed according to the method described by Satoh, (1978) and Ohkawaet al., (1979). Serum Superoxide dismutasedetermination was performed according to the method described by Nishikimi et al., (1972).

\section{Histological examination:}

Specimen from livers from all groups were washed, dehydrated in $85 \%$ alcohol for 24 hours, cleared in xylene and embedded in paraffin wax. Histological sections of 5-6 $\mu \mathrm{m}$ in thickness were cut out, deparaffinized and stained with heamatoxylin and eosin for examination under the light microscope.

\section{Statistical analysis:}

Data was statistically analyzed using SPSS, PC statistical software (version 16, SPSS INC, Chicago, USA). Results were expressed as mean \pm SD. Differences among groups were analyzed by analysis of variance (ANOVA) using Duncan's test as a post hoc test. The P-value of $\leq$ 0.05 was considered to be statistically significant according to Armitageet al., (1987).

\section{Results and Discussion}

Table (1) showed the atherogenic index and lipoproteins ratio of atherosclerotic rats supplemented with raw, roasted and fermented sesame seeds. As expected, feeding rats with high fat diet supplemented with cholesterol caused significant increase in the atherogenic index (positive control group) compared to the negative control one with a mean values of $4.09 \pm 0.29$ vs. $0.71 \pm 0.18$ ,respectively. Interestingly, supplementation of high fat diet with raw, roasted or fermented sesame seeds, showed significant reduction in the atherogenic index at any or all levels of supplementation compared with the positive control group, but they still did not reach the atherogenic index level of negative control group. Regarding the level of supplementation, raw and roasted sesame seeds at level 2 showed significant reduction in the atherogenic index compared to level 1 of supplementation $(1.97 \pm 0.23$ vs. $2.66 \pm 0.42)$ for raw sesame seeds fed group and $1.33 \pm 0.36$ vs. $2.37 \pm 0.37$ for roasted sesame seeds fed group. On the other hand, atherogenic rats fed on fermented sesame seeds showed no significant difference between level 2 and level 1 of supplementation with a mean value of (1.37 \pm 0.09 vs. $1.82 \pm 0.15)$.

Moreover, the lipoproteins ratio (LDL-C/ HDL-c) of positive control group showed the highest lipoproteins ratio in all groups with a mean value of $2.91 \pm 0.30$ compared with the negative control group $(0.46 \pm 0.15)$. Results revealed that rats fed on high fat diet supplemented with raw, roasted or fermented sesame seeds showed reduction in the LDL-C/ HDL-c ratio at all levels of intake (100 and $150 \mathrm{gm} / \mathrm{kg}$ diet) compared with the positive control group. All the forms of supplementations at level (2) caused significant improvement in the LDL-C/ HDL-c ratio compared to level (1) of supplementation. It worth to notice that atherogenic rats fed on high fat diet supplemented with roasted and fermented sesame seeds at level(2) showed remarkable improvement in LDL-C/ HDL-c ratio to the levels that 


\section{Egypt. J. of Nutrition and Health Vol. 15 No. 2 July (2020)}

were not significant with the negative control group representing $(0.87 \pm 0.35,0.90 \pm 0.06$ and $0.46 \pm 0.15)$ ,respectively.

Atherogenic index indicates the magnitude of the potential occurrence of atherosclerosis Prangdimurtiet al., (2007). The higher of atherogenic index, the potential occurrence of atherosclerosis and prevalence of cardiovascular disease was also higher. The total cholesterol and HDL-C levels affect atherogenic index value. Reducing total cholesterol and increasing HDL-C levels reduce the atherogenic index value, so the risk of atherosclerosis will be smaller. Total cholesterol and LDL-Cholesterol levels were positively correlated with the atherogenic index, whereas HDL-cholesterol levels were negatively correlated with the atherogenic index. The higher of HDL-C levels, the atherogenic value is lower, so the risk of atherosclerosis will be smaller (Herpandiet al., 2006)

In accordance with the present study, Sa'adahet al., (2017) concluded that lipid-rich diet for 30 days caused an increase the total cholesterol, LDL-C levels and atherogenic index significantly $(p<0.01)$ compared with control rats.

Khatunet al., (2019) reported that among the 3 dietary treatment groups, it was observed the significant $(p<0.05)$ decrease in the atherogenic index of plasma values in rats fed high lipid diet (HLD) + sesame seeds(SSi) groups compared to HLD group. The study also revealed improvement in atherogenic index of plasma as a result of dietary interventions with HLD+SSi which contribute to cardio-protection.

Results in Table (2) showed the effect of adding raw, roasted and fermented sesame seeds to the high fat diet on the activity of alanine aminotransferase (ALT). Although the positive control group had increased level of ALT in serum compared with the negative control group (healthy) but the difference was not significant with a mean value of $17.33 \pm 5.50 \mathrm{U} / \mathrm{L}$ vs.12.33 $\pm 2.51 \mathrm{U} / \mathrm{L}$ ), respectively . However, rats fed on level(1) of raw, roasted and fermented sesame seeds showed non-significant increment in ALT concentration with mean values of ( $21.33 \pm 2.08 \mathrm{U} / \mathrm{L}, 21.33 \pm 6.51 \mathrm{U} / \mathrm{L}$ and $19.33 \pm$ $2.51 \mathrm{U} / \mathrm{L})$, respectively compared with positive control group $(17.33 \pm 5.50 \mathrm{U} / \mathrm{L})$. When raw and fermented sesame seeds were introduced in the diet at level (2) of intake, ALT enzyme showed slight concentration reduction compared with positive control group, but not significant $(16.33 \pm 3.51 \mathrm{U} / \mathrm{L}$ and $14.66 \pm 2.52 \mathrm{U} / \mathrm{L}$ vs. $17.33 \pm 5.50 \mathrm{U} / \mathrm{L}$, respectively).

Concerning the effect of adding raw, roasted and fermented sesame seeds to the high fat diet on the activity of aspartate aminotransferase (AST) enzyme (Table 1), positive control group had increased level of AST in serum with a mean value of $(11.00 \pm 3.09 \mathrm{U} / \mathrm{L})$ compared with the negative control group $(8.00 \pm 1.00 \mathrm{U} / \mathrm{L})$ but, the difference was not significant. Results revealed that supplementing high fat diet with raw, roasted and fermented sesame seeds in the diet caused significant elevation on serum activity of AST at the tested levels of intake compared with the positive control group.

The effect of sesame seeds on liver function enzymes was illustrated by Ikeda et al., (2003) that sesame seeds contain two unique substances; sesamin and sesameolin, the later has shown to protect liver from oxidative damage. In addition, sesame seeds contain some powerful antioxidants (IP-6, phytate, lignin, pinoresionoly, vitamin E, Lecithin, myristic acid and linolate) which may prevent free radical formation and scavenge free radicals that already formed. Additionally, it is known that dietary supplementation with vitamin $E$ (one of vital component of sesame seeds), the vitamin accumulates in the hepatocytes and not in non-parenchymal cells (Yan et al., 1993). Vitamin E is distributed in the hepatic nuclear fraction in a dose dependent manner, suggesting that vitamin $E$ may 
be an effective antioxidant for preventing oxidative damage to deoxyribonucleic acid (DNA) (Rocchiet al., 1997).

Consequently, Sirato-Yasumoto et al., (2001) stated that sesame seeds can be used without any adverse effect on liver functions and protect the liver from oxidative damage.Mohamed et al., (2018) reported that there was significant decrease in ALT in manipulated group with oral daily dose of sesame seed oil as compared to positive control group and AST had the same trend. Table (3) illustrates the effect of raw, roasted and fermented sesame seeds intake on serum urea and creatinine concentrations of atherosclerotic rats. Results revealed that urea concentration was significantly lower in the positive control group with mean value of $27.06 \pm 2.11 \mathrm{mg} / \mathrm{dl}$ compared with the negative control group fed normal diet $(38.10 \pm 3.85 \mathrm{mg} / \mathrm{dl})$. No significant differences in urea concentrations were recorded between rat groups supplemented with raw and fermented sesame seeds at both levels of supplementation and that of the positive control group. On the other hand, no significant differences in urea concentrations of rats group fed on high fat diet supplemented with roasted sesame seeds at both levels of supplementation and that of negative control group were detected representing $(40.90 \pm 3.62$ $\mathrm{mg} / \mathrm{dl}, 41.16 \pm 6.50 \mathrm{mg} / \mathrm{dl}$ vs. $38.10 \pm 3.85 \mathrm{mg} / \mathrm{dl}$ ), respectively.

Concerning creatinine concentrations in serum, no significant differences were detected between negative control group and positive control group representing $(0.65 \pm 0.10 \mathrm{mg} / \mathrm{dl}$ and $0.61 \pm$ $0.09 \mathrm{mg} / \mathrm{dl}$ ), respectively. All groups supplemented with raw, roasted and fermented sesame seeds at all levels of supplementation showed no significant differences in creatinine concentrations compared to both negative and positive control groups except for rats group fed on fermented sesame seeds for level 2.

Urea is a byproduct from protein breakdown. About $90 \%$ of urea produced is excreted via the kidney (Walmsleyet al., 2010).In kidneys, urea is filtered out of blood by glomeruli and is partially reabsorbed with water (Corbett, 2008).Meanwhile, creatinine which is commonly measured as an index of glomerular function (Treasure, 2003)is a waste product from muscle creatine that is used as energy source during muscle contraction. The normal range of serum creatinine is $0.2-0.8 \mathrm{mg} / \mathrm{dl}$ for rats(Weber et al., 2002) and like urea, it is excreted exclusively through the kidney. Damage to the kidney will thus render the kidney inefficient to excrete both urea and creatinine, hence, it causes their accumulation in the blood (Stevens et al., 2006). Higher values than normal level of blood urea and creatinine will indicate kidney damage. The most frequently used clinical indices for estimating renal function depends upon concentration of urea in the serum (Rosner and Bolton, 2006).

Stevens et al., (2006) indicated that feeding hypercholesterolemic rats with $5 \%$ and $10 \%$ Benni seed (Sesamumindicum) significantly reduced the rising serum urea but not creatinine levels. In addition, Mohamed and Wakwak (2014) reported that the serum levels of urea and creatinine were almost not affected by the treatment of sesame seeds.

Table (4) illustrated the effect of raw, roasted and fermented sesame seeds intake on serum vitamin $\mathrm{E}$ and some oxidative stress markers (malondialdehyde and superoxide dismutase) of atherosclerotic rats

Regarding serum levels of vitamin E, results indicated that the positive control group had lower level than the negative control. It is worth to notice that results revealed that all groups fed on high fat diet supplemented withraw, roasted and fermented sesame seeds at (level 1 and 2) showed obvious significant increase in vitamin $\mathrm{E}$ concentrations compared with the positive control group. 


\section{Egypt. J. of Nutrition and Health Vol. 15 No. 2 July (2020)}

Vitamin E concentrations were higher in groups supplemented with level $2(150 \mathrm{gm} / \mathrm{kg}$ diet $)$ from raw, roasted and fermented sesame seeds than that of level $1(100 \mathrm{gm} / \mathrm{kg}$ diet) supplemented groups. The highest concentration was observed in rats group supplemented with $150 \mathrm{gm} / \mathrm{kg}$ diet fermented sesame seeds representing $(1350 \pm 7.01 \mathrm{mg} / \mathrm{dl})$.

Concerning the first studied marker of oxidative stress; malondialdehyde (MDA) concentration; results showed that there was an increment in MDA concentration of positive control group with a mean value of $(1.26 \pm 0.10 \mathrm{nmol} / \mathrm{ml})$ compared with the negative control group $(0.45 \pm 0.09$ $\mathrm{nmol} / \mathrm{ml}$ ). All treated groups showed significant decrease in MDA concentration compared with the positive control group. Results reported that when rats were fed on level 2 of raw sesame seeds level 1 and level 2 fermented sesame seeds, significant decrease in MDA concentrations were observed with a mean values of $(0.57 \pm 0.11,0.56 \pm 0.10$ and $0.47 \pm 0.09 \mathrm{nmol} / \mathrm{ml})$, respectively with nonsignificant differences when compared with negative control group $(0.45 \pm 0.09 \mathrm{nmol} / \mathrm{ml})$.

Concerning superoxide dismutase (SOD) concentration; as a marker of oxidative stress; positive control group showed a significant decrease in SOD concentration compared with the negative control group $(0.14 \pm 0.11 \mathrm{u} / \mathrm{ml}$ and $0.66 \pm 0.11 \mathrm{u} / \mathrm{ml})$, respectively. Furthermore, feeding atherosclerotic rats on raw, roasted and fermented sesame seeds at the two levels of supplementation; 100 and 150 $\mathrm{gm} / \mathrm{kg}$ high fat diet; resulted in marked increase in SOD concentrations compared with positive control group. It is important to notice that the result of SOD concentration in fermented sesame seeds supplemented group at level 2, showed comparable result to that of negative control group representing $(0.56 \pm 0.09 \mathrm{u} / \mathrm{ml}$ and $0.66 \pm 0.11 \mathrm{u} / \mathrm{ml})$, respectively.

Vitamin $E$ is a potent fat-soluble antioxidant that inhibits lipid peroxidation in biological membranes. Saldeen et al., (1999) reported that the antioxidative effect of $y$-tocopherol on lipid peroxidation in vitro is more potent than that of $\alpha$-tocopherol reported that sesame seed is rich in $\gamma^{-}$ tocopherol, but contains negligible amounts of a-tocopherol (Lemcke-Norojärviet al., 2001) .Elevated serum levels of vitamin $E$ in rats groups fed high fat diet supplemented with raw, roasted and fermented sesame seeds is confirmed by, Robert et al., (2001) that Consumption of moderate amounts of sesame seeds appears to significantly increase plasma $y$-tocopherol and alter plasma tocopherol ratios in humans and is consistent with the effects of dietary sesame seeds observed in rats leading to elevated plasma $\mathrm{Y}$-tocopherol and enhanced vitamin $\mathrm{E}$ bioactivity.

Regarding serum concentrations of vitamin E among various experimental groups, Parker et al., (2000) reported that sesamin played a role in anti-oxidation by inhibiting the catabolism of tocopherol, resulting in enhanced accumulation of tocopherols in plasma and tissues. Moreover, Nakano et al., (2002) stated that sesamin and sesamolin may enhance the effect of vitamin $E$ and reduce lipid peroxidation as antioxidants. Furthermore, Hemalatha and Rao (2004) found that sesame lignans in combination with vitamin $E$ were more effective on lipid peroxidation than as a single compound. In addition, Hanzawaet al., (2013) stated that dietary sesame seed and sesame lignan increase vitamin $\mathrm{E}$ but also vitamin $\mathrm{K}$ concentrations in rat tissues.

Results revealed that supplementation of high fat diet with sesame seeds could improve antioxidant status by increasing SOD activity and lower levels of MDA .This suggests that hyperlipidemia induces lipid peroxidation caused by a systemic increase in oxidative stress. The favorable effect of consuming raw, roasted and fermented sesame seeds on decreasing malondialdehyde concentrations and increasing superoxide dismutase concentrations of atherogenic rats are confirmed by various studies. Wu et al., (2006) observed that sesame ingestion improve 


\section{Hoda S. Ibrahim, et al}

blood lipids and antioxidative ability in animals. In addition, Nishantet al., (2008) stated that the beneficial effects of sesame seeds appeared to be due to its fiber, sterol, polyphenol and flavonoid content, which had an effect on increasing the antioxidant enzyme activities. Moreover, Biswas et al. (2010) fed $18 \%$ sesame protein isolate with or without $2 \%$ cholesterol in comparison with casein to rats for 28 days. The results revealed that dietary sesame protein isolate mitigates lipid peroxidation in both hypercholesterolemia and normo-cholesterolemic diet groups. In addition, Alipooret al., (2012) reported that supplementation with $40 \mathrm{~g} / \mathrm{d}$ of sesame seeds for 60 days enhanced the antioxidant capacity in hyperlipidemic patients.

Accumulating evidence indicates that oxidative stress is an early event in the evolution of hyperlipidemia Ponce-Canchihuamán et al., (2010). Hyperlipidemia is associated with oxidative modification of LDL-C, protein glycation, and glucose autoxidation Yang et al., (2008). In addition, increased cholesterol levels may lead to an elevation in cholesterol pool, which results in altered physical properties of cell membrane, facilitating the leakage of reactive oxygen species (ROS) from the mitochondrial electron system or the activation of NADPH oxidase, eventually culminating in lipid peroxidation and protein oxidation Singhet al., (2017). Lipid peroxidation can disrupt integrity of the phospholipid bilayer and inactivate membrane-bound receptors and enzymes, leading to increased cell permeability and death. Moreover, ROS can diminish the cellular antioxidant capacity by promoting oxidation of the antioxidant enzymes Smatherset al., (2011). In the present study, high fat diet(HFD) induced hyperlipidemia was associated with significant increase in hepatic lipid peroxidation and diminished SOD. Thus, the suppression of hyperlipidemia and subsequent oxidative stress represents an effective approach to protect against CVDs and liver diseases. Herein, supplementation of HFD rats with raw, roasted and fermented sesame seeds resulted in a significant increase in the endogenous enzymes superoxide dismutase (SOD). In addition, reduced lipid peroxidation was observed by a significant decrease in malondialdehyde (MDA) levels in serum samples in different treated groups. Accordingly, sesame seeds may protect against oxidative damage in atherosclerotic rats through inhibition of lipid peroxidation and restoration of antioxidants defense system.

The anti-inflammatory effects of raw, roasted and fermented sesame seeds intake on the paw's thickness of rats after induction of pedal inflammation by formalin are shown in Table (5). Prior to formalin injection, all groups showed non-significant differences in paw's thickness. After three hours of formalin injection, rats fed high fat diet supplemented with $150 \mathrm{gm} / \mathrm{kg}$ diet fermented sesame seeds showed the only significant reduction in the rats inflamed paw's thickness compared with that of positive control group representing $1.83 \pm 0.28 \mathrm{~mm}(26.8 \%$ inhibition ) and $2.50 \pm 0.33 \mathrm{~mm}$ respectively. After six hours of formalin injection there were observed significant reductions in inflamed paw's thickness of rats fed diets supplemented with raw, roasted and fermented sesame seeds at both level 1 and 2 representing $(2.33 \pm 0.28,2.00 \pm 0.40,1.83 \pm 0.28,1.66 \pm 0.23,2.33 \pm 0.76$ and $1.66 \pm 0.28 \mathrm{~mm})$ respectively compared with the positive control rats $(2.83 \pm 0.28 \mathrm{~mm})$.

In the first day of paws' formalin injection, significant reduction in inflamed paw's thickness was observed in almost sesame seeds supplemented groups. The inhibition percentages were $(6.02 \%$ inhibition ) for level ( 1 ) raw sesame seeds fed group and the inhibition for level 1 and 2 roasted and fermented sesame seeds fed groups were greater. Similar trend was noticed in the second day of paws' formalin injection.In the fourth day, only roasted and fermented sesame seeds supplementation at level 2 ( $150 \mathrm{gm} / \mathrm{kg}$ diet ) caused significant reduction in the inflamed paw's thickness representing (33.63 and $41.16 \%$ inhibition) respectively compared with positive control group. 


\section{Egypt. J. of Nutrition and Health Vol. 15 No. 2 July (2020)}

Finally, in the sixth day, all rats fed on high fat diet supplemented with raw, roasted and fermented sesame seeds supplementation at level 1 and 2 revealed significant improvements of inflammation in rat's paw's compared to positive control group. The most pronounce inhibitions of inflammation was observed in the groups of rats supplemented with level 2 of roasted and fermented sesame seeds representing), 30.56\% inhibition) and (43.06\% inhibition) respectively.

Inflammation is a defense mechanism of a body against foreign substances and chronic inflammation persist to different kind of diseases. Wu et al., (2019) reported that the bioactive components of Sesamumindicum L., such as sesamin, sesaminol, sesamol and sesamolin, play essential roles in combating different types of biological and pharmacological concerns and were able to exhibit promising medicinal properties against the diseases. One of the notable properties of sesame lignans is anti-inflammation. Sesame lignans hinder the propagation of inflammatory cytokines and inflammatory mediators, which further leads to alleviating inflammatory-related diseases such as osteoarthritis, cardiovascular disease, neurodegenerative disease, inflammatory bowel disease, diabetic eye disease, lung disease and liver disease. Other sesame extracts apart from the sesame lignans also exhibit mitigation of inflammatory-related pathways. These were proven by the in vivo and in vitro models of inflammatory-induced systems.

Results in the present study revealed that raw, roasted and fermented sesame seeds in general had a protective effect against inflammation and helped in inflammation healing. However, control positive rats had more time for healing when compared with all atherosclerotic rats fed on two different levels of raw, roasted and fermented sesame seeds.

Sesame seeds contain active components tocopherols such as sesamin, sesamolin, etc which have anti-inflammatory effects. Christen et al., (1997) showed that $y$-tocopherol trapped reactive nitrogen oxide species generated during inflammation in vitro. Vitamin $E$ is a lipid-soluble vitamin found in several foods with outstanding antioxidant activity. Analgesic and anti-inflammatory activities of vitamin $E$ have been reported in both humans and rodents (Billiau, and Matthys. 2011). in addition, (Jiang Q., 2014) confirmed that vitamin E, as potent antioxidant, may be able to neutralise free radicals therefore suppressing cytokine production. Vitamin $E$ has also been shown to inhibit COX2, the enzyme involved in inflammatory reactions. Moreover, Cook-Mills, (2013)stated that vitamin E reportedly exerts an anti-inflammatory effect against several inflammatory diseases, such as hypersensitivity reactions, airway inflammation, and several types of arthritis

The obtained results were in the same line with those reported by Ma et al., (2014) that sesamin ; the major lignan in sesame seeds ; was thought to potently attenuate inflammation, but the molecular mechanisms underlying its effects remain largely unknown. Sesamin administration has been shown to suppress tumor necrosis factor- $\alpha$ (TNFa) expression and liver injury. In addition, Deme et al., (2018) stated that the anti-inflammatory molecules associated with sesame oil may contribute the anti-inflammatory and anti-atherosclerotic properties.

Several studies indicated the anti-inflammatory effects of sesame seeds derivatives all over the body. Lee et al., (2013) stated that sesamin; can protect human endothelial cells from HMGB1induced vascular inflammatory diseases. Furthermore, Takahashi et al., (2016) reported that sesamin have antioxidative and anti-inflammatory effects. In addition, Li et al., (2016) concluded that sesamin can inhibit lipopolysaccharide induced inflammation and extracellular matrix catabolism in a rat intervertebral disc. Moreover, Baiet al., (2019) reported that sesamin can stimulate nuclear factor 


\section{Hoda S. Ibrahim, et al}

erythroid-related factor 2-mediated protective defense against oxidative stress and inflammation in colitis via protein kinase $B$ and extracellular signal-regulated kinase.

The mechanism by which sesamin exerts its effect as an anti-inflammatory substance was epxplained by Abe-Kanohet al., (2019). Sesamin is converted into catechol derivatives and further into their glucuronides or sulfates in vivo. Previous research results suggested that sesame catechol (SC1) glucuronides exert the anti-inflammatory effects by inhibiting the Interferon- $\beta$ (IFN- $\beta$ )/ inducible NO synthase (INOS) signaling through macrophage-mediated de-conjugation.

The histological examinations of the liver were shown in photos (1 -8). Photos (1) revealed that the liver of the negative control group showed normal liver histological picture. On the other hand, the positive control group (photo 2) showed severe dilated and engorged portal blood vessels and some fibroblast proliferation in the liver.

Compared with the positive control group, the degree of changes of liver tissue, cells in all experimental groups were alleviated, and the arrangement of hepatocytes was more ordered. The atherosclerotic group of rats fed on raw sesame seeds at level 1 (photo 3 ) revealed fatty changes of the hepatocytes together with area of focal coagulation necrosis. The atherosclerotic rats fed on raw sesame seeds at level 2 (Photo 4) showed focal area of fatty change. The atherosclerotic group of rats fed on roasted sesame seeds at level 1 (Photo 5 ) revealed moderate fatty changes of the hepatocytes. The atherosclerotic rats fed on roasted sesame seeds at level 2 (Photo 6) indicated revealed mild fatty changes of the hepatocytes. The present results indicated that, the atherosclerotic group of rats fed on fermented sesame seeds at level 1 (Photo 7) showed moderate fatty change and individual cell necrosis. The atherosclerotic rats fed on fermented sesame seeds at level 2 (Photo 8) showed mild fatty change.

These results are in agreement with many other researchers who reported that feeding animals with cholesterol-rich diet is commonly used as a model for induction of hypercholesterolemia to study the etiology of hypercholesterolemia-related metabolic disorders and the efficiency of antihypercholesterolemia agents .Liu et al., (2010) reported that the upper panel of the liver of high fat diet fed rats showed fatty degeneration of hepatocytes which was characterized by the appearance of a large lipid vacuole in hepatocytes and a shift in the nucleus to the cell wall (x100). A typical intimal thickening proliferated and disorganized medial smooth muscle cells, and internal elastic lamina with irregular and saw tooth margins were observed in contrast to the normal control. Moreover, Mallick et al., (2016) concluded that themorphological observation include normal histology of liver of control group of rats with radiating chords of hepatocytes around central vein indicate well organized histoarchitecture and severe disorganization of liver cells in cholesterol induced hyperlipidemic rats .

Damaged hepatocytes and blood vessels were seen prominently. Finally, Li et al., (2020) concluded that in the normal control group, liver tissues had normal hepatic cells with preserved cytoplasm, prominent nucleus and central vein. This indicated that the normal diet had no adverse effect on lipid metabolism in rats. The liver cells of the hyperlipidemic group were swollen and arranged loosely and disorderly, and the nucleus was squeezed to one end, which showed that an amount of fat was deposited in the liver, resulting in mild fatty liver disease. 


\section{Egypt. J. of Nutrition and Health Vol. 15 No. 2 July (2020)}

Histological observation results basically supported the results of serum and liver biochemical markers. Azabet al., (2014)reported that orally feeding sesame oil showed normal histological structure of liver tissue with organizes hepatocytes. Also, normal hepatocytes were seen as well as slightly affected ones with a small disorganization in the combination of Seeds of Vicia faba $(\mathrm{SVf})+$ sesame seeds (SSi) when compared with SSi group rats.

Mallicket al., ( 2016 )stated that the treatment of extract from sesame seed (ESS) at the dose $25 \mathrm{mg} / \mathrm{kg}$ body weight/day/rat orally there was evidence of progress in blood vessel and liver tissue but also co-administration of ESS which fed orally sesame seed extract at the dose $50 \mathrm{mg} / \mathrm{kg}$ body weight/day/rat and $75 \mathrm{mg} / \mathrm{kg}$ body weight/day/rat orally were seen well organized liver cells like normal central vein (CV).and normal hepatocytes as well as in control group rats .Li et al., (2020)reported that white sesame seeds can improve liver fatty lesions and lipid metabolism disorder, and can reduce lipid accumulation on the liver, thereby protecting the liver and reducing the risk of fatty liver. The reasons for the observed improvements in liver histology pictures may be that sesame seeds contain active components such as sesamin,sesamolin, and tocopherols, etc. Noguchi et al. (2004)have shown that sesame lignin has the function of protecting liver.

In conclusion, the present study indicates that the bioactive effects of raw sesame seeds and other two treatments on atherosclerosis and inflammation in rats. And suggest that Raw, Roasted and Fermented Sesame Seeds could retard the progression of inflammation and atherosclerotic lesion development and therefore may be useful as a health supplement for the prevention and treatment of inflammation and atherosclerosis diseases

Table (1):

Effect of Raw, Roasted and Fermented Sesame Seeds Intake on Atherogenic Index and Lipoproteins Ratio of Al Atherosclerotic Rats.

\begin{tabular}{|c|c|c|c|c|c|}
\hline \multicolumn{2}{|c|}{ Parameters } & \multicolumn{2}{|c|}{ Al } & \multicolumn{2}{|c|}{ LDL-c/HDL-c } \\
\hline \multirow{2}{*}{ control } & Negative (-) & $0.18^{f}$ & $0.71 \pm$ & \multicolumn{2}{|c|}{$0.46 \pm 0.15^{f}$} \\
\hline & Positive (+) & $0.29^{a}$ & $4.09 \pm$ & $2.91 \pm$ & $0.30^{a}$ \\
\hline \multirow{2}{*}{ Raw sesame seeds } & Level $(I)^{*}$ & $2.66 \pm$ & $0.42^{b}$ & $1.90 \pm$ & $0.39^{b}$ \\
\hline & level $(2)^{\star \star}$ & $1.97 \pm$ & $0.23^{\mathrm{c}, \mathrm{d}}$ & $1.41 \pm$ & $0.22^{c, d}$ \\
\hline \multirow{2}{*}{$\begin{array}{l}\text { Roasted sesame } \\
\text { seeds }\end{array}$} & Level $(\mathrm{I})^{*}$ & $2.37 \pm$ & $0.37^{b, c}$ & $1.76 \pm$ & $0.32^{b, c}$ \\
\hline & level $(2)^{\star \star}$ & $1.33 \pm$ & $0.36^{e}$ & $0.87 \pm$ & $0.35^{\mathrm{e}, \mathrm{f}}$ \\
\hline \multirow{2}{*}{$\begin{array}{l}\text { Fermented sesame } \\
\text { seeds }\end{array}$} & Level $(\mathrm{I})^{*}$ & $1.82 \pm$ & $0.15^{\mathrm{d}, \mathrm{e}}$ & $1.24 \pm$ & $0.14^{\mathrm{d}, \mathrm{e}}$ \\
\hline & level $(2)^{\star *}$ & $1.37 \pm$ & $0.09^{e}$ & $0.90 \pm$ & $0.06^{e, f}$ \\
\hline
\end{tabular}

- Results are expressed as means \pm SD.

-Values at the same column sharing the same superscript letters are not significantly different
(Ps 0.05).
- *level (1) = $100 \mathrm{gm}$. $/ \mathrm{kg}$ diet
- ** level (2) =150 gm. $/ \mathrm{kg}$ diet

Al: Atherogenic Index HDL-C: Serum High Density Lipoprotein Cholesterol

LDL-C: Low Density Lipoprotein Cholesterol . 
Table (2):

Effect of Raw, Roasted and Fermented Sesame Seeds Intake on Serum Liver Function Enzymes of Atherosclerotic Rats.

\begin{tabular}{|c|c|c|c|}
\hline \multicolumn{2}{|c|}{$\begin{array}{ll}\text { Groups } & \text { Parameters } \\
\end{array}$} & $\begin{array}{l}\mathrm{ALT} \\
(\mathrm{U} / \mathrm{L})\end{array}$ & $\begin{array}{l}\text { AST } \\
(\mathrm{U} / \mathrm{L})\end{array}$ \\
\hline \multirow{2}{*}{ control } & Negative (-) & $12.33 \pm 2.51^{c}$ & $8.00 \pm 1.00^{d}$ \\
\hline & Positive (+) & $17.33 \pm 5.50^{\mathrm{a}, \mathrm{c}}$ & $11.00 \pm 3.09^{c, d}$ \\
\hline \multirow{2}{*}{ Raw sesame seeds } & Level $(I)^{*}$ & $21.33 \pm 2.081^{a}$ & $27.66 \pm 4.16^{a}$ \\
\hline & level $(2)^{\star \star}$ & $16.33 \pm 3.51^{a, c}$ & $18.00 \pm 6.55^{b, c}$ \\
\hline \multirow{2}{*}{$\begin{array}{l}\text { Roasted sesame } \\
\text { seeds }\end{array}$} & Level $(I)^{*}$ & $21.33 \pm 6.51^{a}$ & $17.66 \pm 5.13^{b, c}$ \\
\hline & level $(2)^{\star *}$ & $19.66 \pm 3.05^{a, b}$ & $20.66 \pm 5.68^{a, b}$ \\
\hline \multirow{2}{*}{$\begin{array}{l}\text { Fermented sesame } \\
\text { seeds }\end{array}$} & Level $(I)^{*}$ & $19.33 \pm 2.51^{a, b}$ & $20.00 \pm 3.03^{b}$ \\
\hline & level $(2)^{* *}$ & $14.66 \pm 2.516^{b, c}$ & $24.33 \pm 3.21^{b}$ \\
\hline
\end{tabular}

- Results are expressed as means \pm SD.

- Values at the same column sharing the same superscript letters are not significantly different $(P \leq 0.05) . \quad-\quad$ level $(1)^{*}=100 \mathrm{gm} . / \mathrm{kg}$ diet $\quad-$ level $(2){ }^{* *}=150 \mathrm{gm} . / \mathrm{kg} \mathrm{diet}$

- ALT: Alanine amino transferase. -AST: Aspartate amino transferase.

Table (3):

Effect of Raw, Roasted and Fermented Sesame Seeds Intake on Serum Urea and Creatinine Concentrations of Atherosclerotic Rats.

\begin{tabular}{l|c|c|c}
\hline \multicolumn{2}{c|}{ Parameters } & $\begin{array}{c}\text { Urea } \\
\text { Groups }\end{array}$ & $\begin{array}{c}\text { Creatinine } \\
(\mathrm{mg} / \mathrm{dl})\end{array}$ \\
\hline \multirow{3}{*}{ control } & Negative $(-)$ & $38.10 \pm 3.85^{\mathrm{a}, \mathrm{b}}$ & $0.65 \pm 0.104^{\mathrm{a}}$ \\
\cline { 2 - 4 } & Positive (+) & $27.06 \pm 2.11^{\mathrm{c}}$ & $0.61 \pm 0.09^{\mathrm{a}, \mathrm{b}}$ \\
\hline \multirow{2}{*}{ Raw sesame seeds } & Level $(\mathrm{I})^{\star}$ & $31.33 \pm 2.289^{\mathrm{c}}$ & $0.69 \pm 0.15^{\mathrm{a}}$ \\
\cline { 2 - 4 } & level $(2)^{\star *}$ & $31.63 \pm 3.85^{\mathrm{b}, \mathrm{c}}$ & $0.74 \pm 0.02^{\mathrm{a}}$ \\
\hline \multirow{2}{*}{ Roasted sesame seeds } & Level $(\mathrm{I})^{\star}$ & $40.90 \pm 3.62^{\mathrm{a}}$ & $0.67 \pm 0.05^{\mathrm{a}}$ \\
\cline { 2 - 4 } & level $(2)^{\star *}$ & $41.16 \pm 6.50^{\mathrm{a}}$ & $0.66 \pm 0.11^{\mathrm{a}}$ \\
\hline \multirow{2}{*}{$\begin{array}{l}\text { Fermented sesame } \\
\text { seeds }\end{array}$} & Level $(\mathrm{I})^{\star}$ & $29.80 \pm 2.08^{\mathrm{c}}$ & $0.65 \pm 0.11^{\mathrm{a}}$ \\
\cline { 2 - 4 } & level $(2)^{* *}$ & $26.10 \pm 4.24^{\mathrm{c}}$ & $0.47 \pm 0.06^{\mathrm{b}}$ \\
\hline
\end{tabular}

- Results are expressed as means \pm SD.

- Values at the same column sharing the same superscript letters are not significantly different $(P \leq 0.05)$.

level $(1)^{*}=100 \mathrm{gm} . / \mathrm{kg}$ diet $\quad-$ level $(2){ }^{* *}=150 \mathrm{gm} . / \mathrm{kg}$ diet 
Egypt. J. of Nutrition and Health Vol. 15 No. 2 July (2020)

Table (4):

Effect of Raw, Roasted and Fermented Sesame Seeds Intake on Serum Vitamin E and Some Oxidative Stress Markers of Atherosclerotic Rats.

\begin{tabular}{|c|c|c|c|c|}
\hline \multicolumn{2}{|c|}{$\begin{array}{l}\text { Parameters } \\
\text { Groups }\end{array}$} & $\begin{array}{c}\text { Vitamin E } \\
(\mathrm{mg} / \mathrm{dl})\end{array}$ & $\begin{array}{c}\text { MDA } \\
(\mathrm{nmol} / \mathrm{ml})\end{array}$ & $\begin{array}{l}\text { SOD } \\
(\mathrm{u} / \mathrm{ml})\end{array}$ \\
\hline \multirow[b]{2}{*}{ control } & Negative (-) & $176.81 \pm 6.48^{g}$ & $0.45 \pm 0.09^{d}$ & $0.66 \pm 0.11^{a}$ \\
\hline & Positive (+) & $132.80 \pm 6.94^{h}$ & $1.263 \pm 0.10^{\mathrm{a}}$ & $0.14 \pm 0.11^{d}$ \\
\hline \multirow{2}{*}{$\begin{array}{l}\text { Raw sesame } \\
\text { seeds }\end{array}$} & Level $(\mathrm{I})^{*}$ & $480.00 \pm 7.00^{f}$ & $0.90 \pm 0.10^{b}$ & $0.27 \pm 0.09^{c}$ \\
\hline & level $(2)^{* *}$ & $752.69 \pm 7.10^{\mathrm{e}}$ & $0.57 \pm 0.11^{\mathrm{c}, \mathrm{d}}$ & $0.37 \pm 0.09^{b}$ \\
\hline \multirow{2}{*}{$\begin{array}{l}\text { Roasted } \\
\text { sesame seeds }\end{array}$} & Level $(I)^{*}$ & $848.66 \pm 6.95^{c}$ & $0.72 \pm 0.11^{\mathrm{b}, \mathrm{c}}$ & $0.34 \pm 0.09 b$ \\
\hline & level $(2)^{\star *}$ & $1269.28 \pm 7.05^{\mathrm{b}}$ & $0.75 \pm 0.11^{b}$ & $0.41 \pm 0.10^{b}$ \\
\hline \multirow{2}{*}{$\begin{array}{l}\text { Fermented } \\
\text { sesame seeds }\end{array}$} & Level $(I)^{*}$ & $833.91 \pm 6.95^{d}$ & $0.56 \pm 0.10^{c, d}$ & $0.36 \pm 0.11^{b}$ \\
\hline & level $(2)^{* *}$ & $1350.52 \pm 7.01^{a}$ & $0.47 \pm 0.09^{d}$ & $0.56 \pm 0.09^{a}$ \\
\hline
\end{tabular}

- Results are expressed as means \pm SD.

- Values at the same column sharing the same superscript letters are not significantly different $(P \leq 0.05) . \quad-$ level $(1)^{*}=100 \mathrm{gm} . / \mathrm{kg}$ diet $\quad-$ level $(2){ }^{* *}=150 \mathrm{gm} . / \mathrm{kg}$ diet -MDA : Malondialdehyde - SOD: Superoxide dismutase 
Hoda S. Ibrahim, et al

Table (5):

Effect of Raw, Roasted and Fermented Sesame Seeds Intake on the Paw's Thickness of Atherosclerotic Rats after the Induction of Pedal Inflammation.

\begin{tabular}{|c|c|c|c|c|c|c|c|c|}
\hline \multicolumn{2}{|c|}{ Groups $\quad$ Duration } & $\begin{array}{l}\text { Zero time } \\
\quad(\mathrm{mm})\end{array}$ & $\begin{array}{l}3 \mathrm{Hr} . \\
(\mathrm{mm})\end{array}$ & $\begin{array}{l}6 \mathrm{Hr} . \\
(\mathrm{mm})\end{array}$ & $\begin{array}{l}1 \text { Day } \\
(\mathrm{mm})\end{array}$ & $\begin{array}{l}2 \text { Day } \\
(\mathrm{mm})\end{array}$ & $\begin{array}{l}\text { 4 Day } \\
(\mathrm{mm})\end{array}$ & $\begin{array}{l}6 \text { Day } \\
(\mathrm{mm})\end{array}$ \\
\hline \multirow{2}{*}{\multicolumn{2}{|c|}{ Positive Control }} & $1.66 \pm 0.5$ & $2.50 \pm$ & $2.83 \pm$ & $2.66 \pm$ & $2.43 \pm$ & $2.26 \pm$ & $2.16 \pm$ \\
\hline & & $7^{\mathrm{a}}$ & $0.33^{\mathrm{a}}$ & $0.28^{\mathrm{a}}$ & $0.28^{a}$ & $0.40^{a}$ & $0.24^{\mathrm{a}}$ & $0.28^{a}$ \\
\hline \multirow{6}{*}{$\begin{array}{c}\text { Raw } \\
\text { sesame } \\
\text { seeds }\end{array}$} & \multirow{2}{*}{ Level $(I)^{*}$} & \multirow{2}{*}{$1.67 \pm 0.29^{\mathrm{a}}$} & $2.33 \pm$ & $2.33 \pm$ & $2.50 \pm$ & $2.30 \pm$ & $2.03 \pm$ & $2.00 \pm$ \\
\hline & & & $0.28^{a, b}$ & $0.28^{b}$ & $0.50^{\mathrm{a}}$ & $0.40^{\mathrm{a}}$ & $0.05^{\mathrm{a}}$ & $0.40^{b}$ \\
\hline & Inhibition\% & - & 6.8 & 17.67 & 6.02 & 5.35 & 10.18 & 7.41 \\
\hline & \multirow{2}{*}{ level $(2)^{\star \star}$} & $1.33 \pm$ & $2.16 \pm$ & $2.00 \pm$ & $1.83 \pm$ & $1.83 \pm$ & $1.83 \pm$ & $1.66 \pm$ \\
\hline & & $0.28^{a}$ & $0.28^{\mathrm{a}, \mathrm{b}}$ & $0.40^{b, c}$ & $0.28^{b, c}$ & $0.28^{b}$ & $0.28^{\mathrm{a}, \mathrm{b}}$ & $0.28^{c}$ \\
\hline & Inhibition\% & 19.88 & 13.6 & 29.33 & 31.21 & 24.7 & 19.03 & 23.15 \\
\hline \multirow{6}{*}{$\begin{array}{l}\text { Roasted } \\
\text { sesame } \\
\text { seeds }\end{array}$} & \multirow{2}{*}{ Level $(I)^{*}$} & $1.50 \pm$ & $2.30 \pm$ & $1.83 \pm$ & $1.83 \pm$ & $1.83 \pm$ & $1.83 \pm$ & $1.83 \pm$ \\
\hline & & $0.26^{a}$ & $0.50^{\mathrm{a}}$ & $0.28^{b, c}$ & $0.28^{b, c}$ & $0.28^{b}$ & $0.28^{a, b}$ & $0.28^{\mathrm{b}, \mathrm{c}}$ \\
\hline & Inhibition\% & 9.64 & 8 & 35.34 & 31.21 & 24.7 & 19.03 & 15.28 \\
\hline & \multirow{2}{*}{ level $(2)^{\star \star}$} & $1.33 \pm$ & $2.00 \pm$ & $1.66 \pm$ & $1.66 \pm$ & $1.50 \pm$ & $1.50 \pm$ & $1.50 \pm$ \\
\hline & & $0.28^{a}$ & $0.40^{\mathrm{a}, \mathrm{c}}$ & $0.23^{c}$ & $0.28^{\mathrm{b}, \mathrm{c}}$ & $0.24^{b}$ & $0.26^{b, c}$ & $0.26^{c, d}$ \\
\hline & Inhibition\% & 19.88 & 20 & 41.35 & 37.6 & 38.28 & 33.63 & 30.56 \\
\hline \multirow{6}{*}{$\begin{array}{c}\text { Fermented } \\
\text { sesame } \\
\text { seeds }\end{array}$} & \multirow{2}{*}{ Level $(I)^{*}$} & $1.33 \pm$ & $2.33 \pm$ & $2.33 \pm$ & $2.16 \pm$ & $2.00 \pm$ & $1.83 \pm$ & $1.83 \pm$ \\
\hline & & $0.28^{a}$ & $0.57^{a, b}$ & $0.76^{b}$ & $0.57^{b}$ & $0.50^{\mathrm{a}, \mathrm{b}}$ & $0.28^{\mathrm{a}, \mathrm{b}}$ & $0.28^{\mathrm{b}, \mathrm{c}}$ \\
\hline & Inhibition\% & 19.88 & 6.8 & 17.67 & 18.8 & 17.7 & 19.03 & 15.28 \\
\hline & \multirow{2}{*}{ level $(2)^{\star *}$} & $1.30 \pm$ & $1.83 \pm$ & $1.66 \pm$ & $1.50 \pm$ & $1.50 \pm$ & $1.33 \pm$ & $1.23 \pm$ \\
\hline & & $0.27^{a}$ & $0.28^{c}$ & $0.28^{c}$ & $0.26^{c}$ & $0.26^{b}$ & $0.16^{c}$ & $0.14^{d}$ \\
\hline & Inhibition\% & 21.69 & 26.8 & 41.35 & 43.61 & 38.28 & 41.15 & 43.06 \\
\hline
\end{tabular}

- Results are expressed as means \pm SD.

- Values at the same column sharing the same superscript letters are not significantly different $(P \leq 0.05) . \quad-$ level $(1){ }^{*}=100 \mathrm{gm} . / \mathrm{kg}$ diet $\quad-$ level $(2){ }^{* *}=150 \mathrm{gm} . / \mathrm{kg} \mathrm{die}$ 


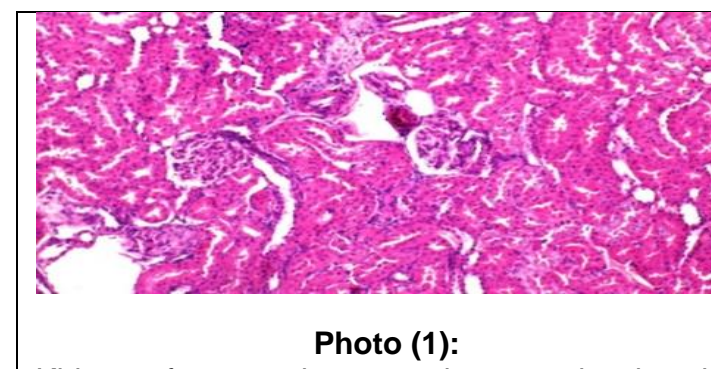

Kidney of a negative control group showing the normal histological structure of renal parenchyma (H \& EX 400).

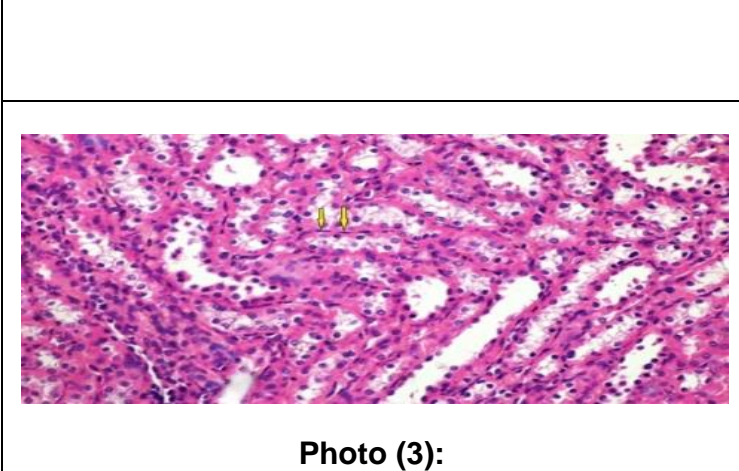

Kidney of atherosclerosistic rats fed on basal diet +100 $\mathrm{gm}$. $/ \mathrm{kg}$ diet milled raw sesame seeds showing Kidney revealing necrobiotic changes of the tubular epithelium manifested by strongly eosirophilic cytoplasm and pycrolic nuclei mean while the interistial tissue revealing mild fibrous connective tissue proliferation (H \& EX 400).

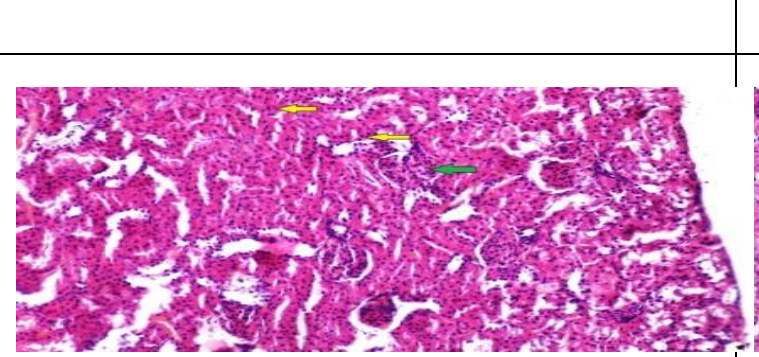

Photo (5):

Kidney of atherosclerosistic rats fed on basal diet $+100 \mathrm{gm}$. $/ \mathrm{kg}$ diet milled roasted sesame seeds showing necrosis of renal tubular epithelium and atrophied glomeruli with proliferation of fibroplast in the interistial tissue (H \& EX 400).

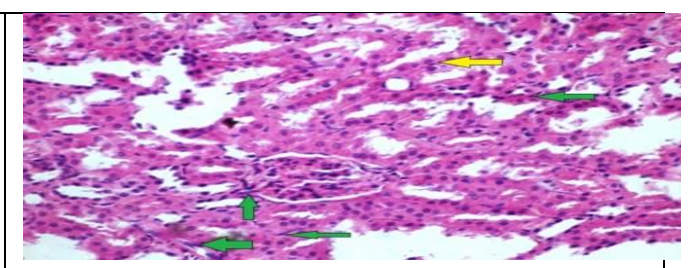

Photo (2):

Kidney of a positive control group showing necrobiotic changes of renal tubular epithelium and fibroplast proliferation in the renal glomeruli and the renal interistial tissue (H \& EX 400).

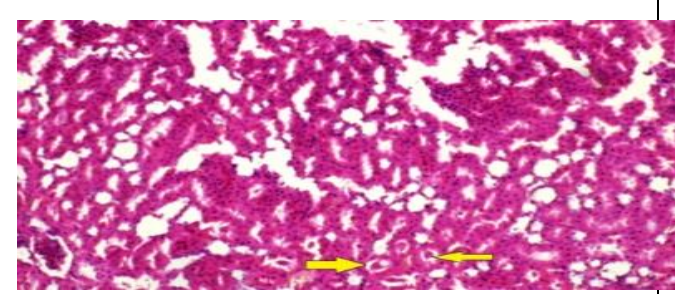

Photo (4):

Kidney of atherosclerosistic rats fed on basal diet $+150 \mathrm{gm}$. $/ \mathrm{kg}$ diet milled raw sesame seeds showing renal cast (H \& EX 400).

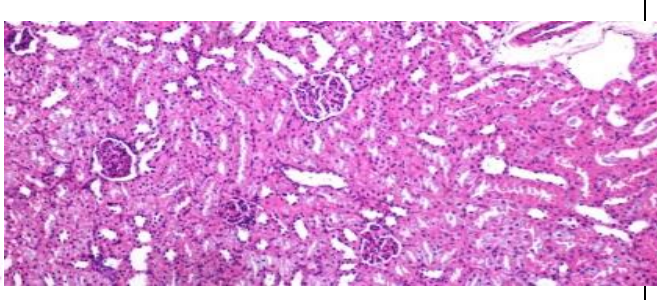

Photo (6):

Kidney of atherosclerosistic rats fed on basal diet $+150 \mathrm{gm}$. $/ \mathrm{kg}$ diet milled roasted sesame seeds showing necrobiotic changes in the renal tubular epithelium and renal cast $(\mathrm{H}$ \& EX 400). 
Hoda S. Ibrahim, et al 


\section{Egypt. J. of Nutrition and Health Vol. 15 No. 2 July (2020)}

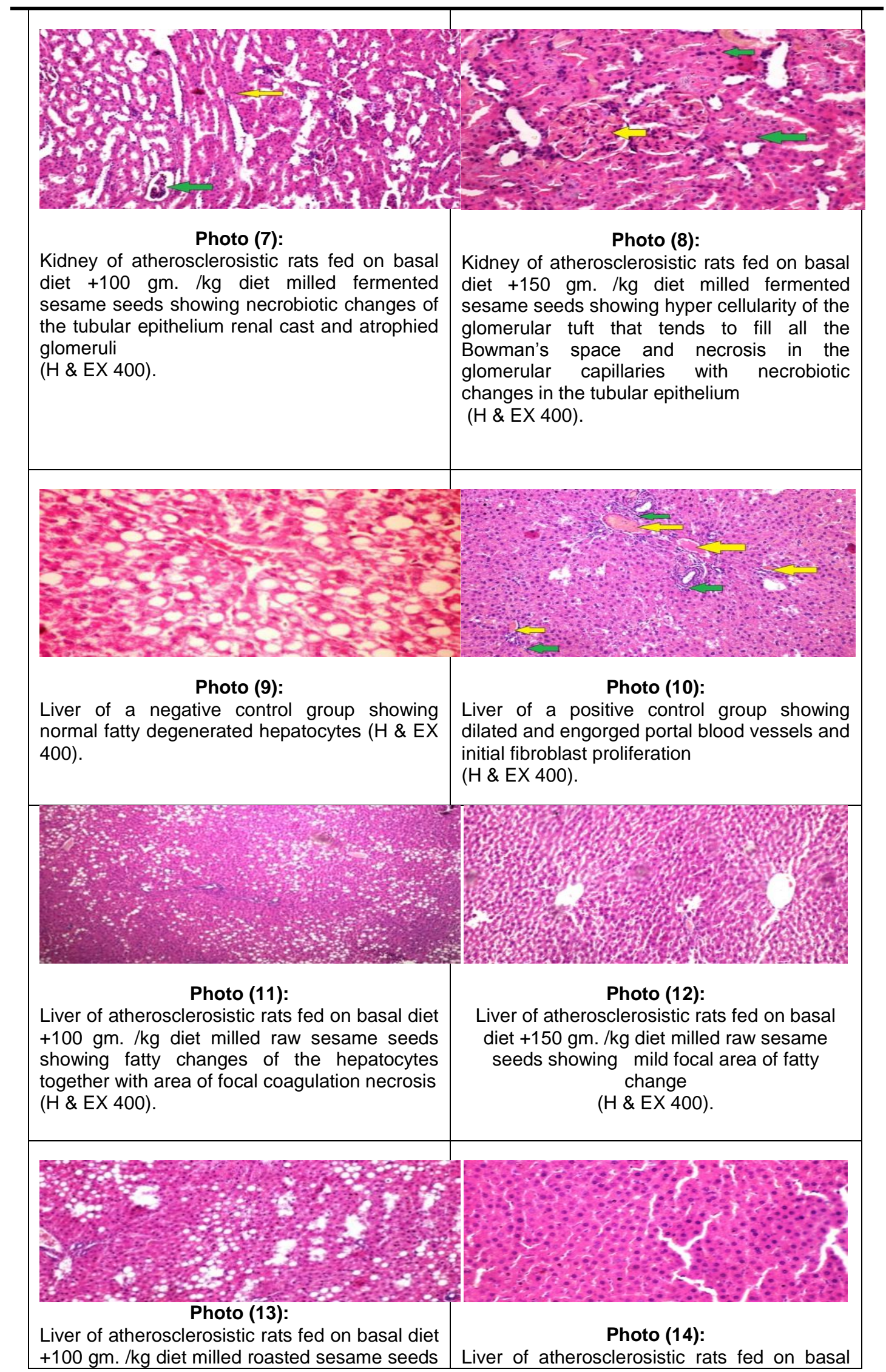


Hoda S. Ibrahim, et al

\begin{tabular}{|l|l|l|}
\hline $\begin{array}{l}\text { showing moderate fatty changes of the } \\
\text { hepatocytes. (H \& EX 400). }\end{array}$ & $\begin{array}{l}\text { diet }+150 \mathrm{gm} \text {. } / \mathrm{kg} \text { diet milled roasted sesame } \\
\text { seeds showing some fatty changes of the } \\
\text { hepatocytes (H \& EX 400). }\end{array}$ \\
\hline $\begin{array}{l}\text { Liver of atherosclerosistic rats fed on basal diet } \\
+100 \text { gm. /kg diet milled fermented sesame } \\
\text { seeds showing moderate fatty change and } \\
\text { hepatocytes showing individual cell necrosis. } \\
\text { (H \& EX 400). }\end{array}$ & $\begin{array}{l}\text { Liver of atherosclerosistic rats fed on basal } \\
\text { diet }+150 \text { gm. } / \mathrm{kg} \text { diet milled fermented } \\
\text { sesame seeds showing moderate fatty } \\
\text { change and few hepatocytes showing } \\
\text { individual cell necrosis } \\
\text { (H \& EX 400). }\end{array}$ \\
\hline
\end{tabular}

\section{References}

Abe-KanohN., Kunimoto Y., Takemoto D., Ono Y., Shibata H., Ohnishi K. and Kawai Y. (2019): Sesamin Catechol Glucuronides Exert Anti-inflammatory Effects by Suppressing Interferon $\beta$ and Inducible Nitric Oxide Synthase Expression through Deconjugation in Macrophage-like J774.1 Cells. Journal of Agricultural and Food Chemistry, 67, 27, 7640-7649.

Ajaikumar B.K., Bethsebie L.S., Kishore B., Choudhary H., Sahdeo P., Alok C.B., Subash C.G. and Bharat B.A., (2018):

Chronic diseases, inflammation, and spices: how are they linked? Review; Journal of Translational Medicine, 16:14.

Alipoor B., Haghighian M., Sadat B. and JafarabadiM., (2012):

Effect of sesame seed on lipid profile and redox status in hyperlipidemic patients. International Journal of Food Sciences and Nutrition, 63(6):674-8.

Armitage G., Berry G., Publications S. and Oxford U., (1987):

Statistical methods in medical research, Statistic in medicine, P. No. of pages: 559.

Azab A.E., (2014):

Hepatoprotective effect of sesame oil against lead induced liver damage in albino mice: Histological and biochemical studies, American Journal of Bio Science. 2014; 2(2): 1-11.

Bai X., Gou X., Cai P., Xu C., Cao L., Zhao Z., Huang M. and Jin J., (2019):

SesaminEnhances Nrf2-Mediated Protective Defense against Oxidative Stress and Inflammation in Colitis via AKT and ERK Activation. Oxidative Medicine and Cellular Longevity Article ID 2432416, Pages 1-20. 


\section{Egypt. J. of Nutrition and Health Vol. 15 No. 2 July (2020)}

Billiau A., and Matthys P., (2011):

Collagen-induced arthritis and related animal models: how much of their pathogenesis is autoimmune, how much is auto-inflammatory? Cytokine and Growth Factor Reviews 22: 339-344.

Biswas A., Dhar P., and Ghosh S., (2010):

"Antihyperlipidemic effect of sesame (Sesamumindicum L.) Protein isolate in rats fed a normal and high cholesterol diet," Journal of Food Science, vol. 75, no. 9, pp. H274-H279.

Chaney L.A. and Marbach P.E., (1962):

Modified reagents for determination of urea and ammonia. Clinical chemistry Dokl Biochem Biophys, 8:130-2.

Christen S.W., Woodall A.A., Shigenaga M.K., Southwell-Keely P.T., Duncan M.W. and Ames B.N., (1997):

$\mathrm{Y}$-Tocopherol traps mutagenic electrophiles such as $\mathrm{NOx}$ and complements $\alpha$-tocopherol: physiological implications. Proc. National Academy of Sciences U.S.A., 94:3217-3222.

Cook-Mills J.M., (2013):

Isoforms of vitamin E differentially regulate PKC a and inflammation: a review, Journal of Clinical \& Cellular Immunology 4(137).

Corbett J.V., (2008):

Laboratory tests and diagnostic procedures with nursing diagnoses; 7th Edn 90-107.ISBN-13

Deme P., Narasimhulu C. and Parthasarathy S., (2018):

Identification and evaluation of anti-inflammatory properties of aqueous components extracted from sesame (Sesamumindicum) oil. Journal of Chromatography B,Volumes 1087-1088, 15 June 2018, Pages 61-69.

Hama J.R., (2017):

Comparison of fatty acid profile changes between unroasted and roasted brown sesame (SesamumindicumL.) seeds oil; International Journal of Food Properties. 20(5) 957-967.

Hanglund O.,Luostarinen R. and Wallin R., (1991):

Effect of fish oil on triglycerides, cholesterol, fibrinogen and malondi aldehyde in humans supplemented with vitamin E. Journal of Nutrition, 37:740-748.

Hanzawa F., Nomura S., Sakuma E., Uchida T., Ikeda S., (2013):

Dietary Sesame Seed and Its Lignan, Sesamin, Increase Tocopherol and Phylloquinone Concentrations in Male Rats. Journal of Nutrition, Volume 143, Issue 7, Pages 1067-1073.

Hassan M.H., (2012):

Studies on Egyptian Sesame Seeds (Sesamumindicum L.) and Its Products 1Physicochemical Analysis and Phenolic Acids of Roasted Egyptian Sesame seeds (Sesamumindicum L.). World Journal of Dairy \& Food Sciences 7 (2): 195-201.

Hemalatha S. and Rao M., (2004): 


\section{Hoda S. Ibrahim, et al}

Sesame lignans enhance antioxidant activity of vitamin E in lipid peroxidation systems. Mol Cell Biochem262, 195-202.

Henry R.J., (1964):

Clinical Chemistry, Principles and Techniques. Hoeber Medical, Harper-Row.190, 287.

Herpandi M., Astawan T., Wresdiyati N. and Palupi A., (2006):

Perubahan Profil Lipida, Kolesterol Digestadan Asam Propionatpada Tikusdengan Diet Tepung RumputLaut. Jurnal Teknologidan Industri Pangan, Volume XVII No. 3. Hal: 227-232.

Ikeda S., Kagaya M., Kobayashi K., Tohyama T., Kiso Y., Higuchi N. and Yamashita K.,(2003): Dietary sesame lignans decrease lipid peroxidation in rats fed docosahexaenoic acid. Journal of Nutritional Science and Vitaminology (Tokyo), 49 (4), p. 270.

Jiang Q., (2014):

Natural forms of vitamin E: metabolism, antioxidant, and anti-inflammatory activities and their role in disease prevention and therapy. Review Article. Free Radical Biology and Medicine, Volume 72, Pages 76-90.

Khatun H., Das K., Nandi D. and Chattopadhyay A., (2019):

Supplementation of seed dust of Viciafaba and sesame ameliorates high lipid diet-induced dyslipidemia in rats, Current Research in Nutrition and Food ScienceJournal, 7(1).

Lee W., Ku S. , Kim J., Lee T., and Bae J., (2013):

"Inhibitory effects of epi-sesamin on HMGB1-induced vascular barrier disruptive responses in vitro and in vivo," Toxicology and Applied Pharmacology, vol. 267, no. 3, pp. 201-208.

Lemcke-Norojarvi M., Kamal-EldinA., Appelqvist L. , DimbergL. , OhrvallM. and VessbyB., (2001):

Corn and sesame oils increase serum $\mathrm{Y}$-tocopherol concentrations in healthy Swedish women. Journal of Nutrition.131:1195-1201.

Li K., Li Y., Xu B., Mao L., and Zhao J., (2016):

"Sesamin inhibits lipopolysaccharide-induced inflammation and extracellular matrix catabolism in rat intervertebral disc," Connective Tissue Research, volume 57, no. 5, pp. 347-359.

Li C., Li Y., Ma Y., Wang D., Zheng Y. and Wang X., (2020):

Effect of black and white sesame on lowering blood lipids of rats with hyperlipidemia induced by high-fat diet, Grain \& Oil Science and Technology.

Liu1 J., Jia L., Li B., Lan L., Ge Q., Zheng H. and Deng H., (2010):

Adiponectin suppresses inflammatory responses at the early phase of atherosclerosis in hyperglycemic rats. Molecular Medicine RE POR TS 3: 323-328.

Ma J., Ding J., Zhang L. and Liu C., (2014):

Hepatoprotective properties of sesamin against $\mathrm{CCl} 4$ induced oxidative stress-mediated apoptosis in mice via JNK pathway; Journal of Food and Chemical Toxicology, 64, 41-48

Makinde F., Akinoso R., (2014): 


\section{Egypt. J. of Nutrition and Health Vol. 15 No. 2 July (2020)}

Comparison between the nutritional quality of fl our obtained from raw, roasted and fermented sesame (Sesamumindicum L.) seed grown in Nigeria. Journal of Acta Scientiarum Polonorum Technologia Alimentaria, 13(3), 309-319.

Mallick S., Mandal M., Roy S., Pradhan S., Mandal S., Maiti R., Nandi D., Dasgupta R. and Das K., (2016):

Effect of phytosterol extract from sesame seed on experimentally induced hyperlipidemic rats: dose dependent study. International Journal of pharma and bio sciences, 7(1): (B) $370-377$.

Mohamed N.E. and Wakwak M.M., (2014):

Effect of sesame seeds or oil supplementation to the feed on some physiological parameters in Japanese Quail; Journal of Radiation Research and Applied Sciences. Volume 7, Issue 1:101-109.

Mohamed G.A., TahaH. A., El-Khamissi Z.A. and Ali M. A., (2018):

Potency of somali red sesame seed oil as a prophylactic agent against hyperlipidemia in male albino rats fed on fatty diet. Zagazig Journal of Agricultural Research, Volume: 45 No. (5) :1711-1720.

Mozaffarian D., Micha R. and Wallace S., (2010):

Effects on coronary heart disease of increasing polyunsaturated fat in place of saturated fat: a systematic review and meta-analysis of randomized controlled trials. PLoS Medicine 7, e1000252.

Nakano D., Itoh C., Takaoka M., Kiso Y., Tanaka T., Matsumura Y., (2002):

Antihypertensive effect of sesamin. IV. Inhibition of vascular superoxide production by sesamin, Biological and Pharmaceutical Bulletin, 25: 1247- 1249.

Niki E., (2011):

Do free radicals play causal role in atherosclerosis? Low density lipoprotein oxidation and vitamin E revisited, Journal of Clinical Biochemistry and Nutrition, 48, 3.

Nishant P., Visavadiya A., Narasimhacharya R., (2008):

Sesame as a hypo-cholesteraemic and antioxidant dietary component. Food and Chemical Toxicology, 46 (6), p. 1889

Nishikimi M., Roa N., and Yogi K., (1972):

The occurrence of superoxide anion in the reaction of reduced phenazine methosulfate and molecular oxygen, Biochemical Biophysical Research Communications,46, 849- 854.

NitiPathak A., Bhaduri A., and Ashwani K., (2019):

Sesame: Bioactive Compounds and Health Benefits. Bioactive Molecules in Foodpp 181-200.

Noguchi T., Ikeda K., Sasaki Y., Yamamoto J., Seki J., Yamagata K.and et al., ( 2001): Effects of vitamin $E$ and sesamin on hypertension and cerebral thrombogenesis in strokeprone spontaneously hypertensive rats. HypertensionResearch, 24:735e42. 
Northover, B. and Subramanian, G.(1962):

Pedal inflammation induced by chemical agents; British Journal of Pharmacology, 18,346-349.

Ohkawa H., Ohishi W., Yagi K. and Biochem A. (1979):

Assay for lipid peroxides in animal tissues by thiobarbituric acid reaction, Journal ofAnalytical Biochemistry,95, 351.

Parker R.S., Sontag T.J. and Swanson J.E. (2000):

Cytochrome P4503A-dependent metabolism of tocopherols and inhibition by sesamin.Jornal of Biochemical and Biophysical Research Communications, 277:531-534.

Ponce-Canchihuamán J., Pérez-Méndez O., Hernández-Muñoz R., Torres-Durán P. and JuárezOropeza M., (2010):

Protective effects of Spirulina maxima on hyperlipidemia and oxidative-stress induced by lead acetate in the liver and kidney; Lipids in Health and Diseases,9, 35.

Prangdimurti E., Palupidan N. and Zakaria F., (2007):

Metode Evaluasi Nilai Biologis Karbohidratdan Lemak. Module-Learning;ENBP, Departemenllmu \& Teknologi Pangan-Fateta-IPB, page 1:17.

Reeves P., Nielsen F. and Fahmy G., (1993):

Purified diets for laboratory rodents: Final report of the American Institute of Nutrition writing committee on the reformulation of the AIN- 76 a rodent diet. Journal of Nutrition, 123(51): $1939-1951$.

Rizki H. Nabloussi A., Kzaiber F., Elharfi M., Ennahli S. and Hanine H., (2016):

Evaluation Of The Effects Of Processing Parameters Of Roasting On The Antioxidant Activity And Bioactive Molecules Of Seeds Oil Of Sesame (Sesamumlndicum .L). IOSR Journal of Environmental Science,Toxicology and Food Technology (IOSR-JESTFT) e-ISSN: 23192402, p- ISSN: 2319-2399. Volume 10, Issue 6 Ver. I, PP 84-92.

Robert V., Cooney Laurie J., Custer Leila O. and Adrian A., (2001):

Effects of Dietary Sesame Seeds on Plasma Tocopherol Levels. Nutrition and Cancer, 39(1):66-71 .

Rocchi E., Seium Y., Camellinin L., Casalgrandi G., Borghi A., D'Alimontc R. and et al. (1997): Hepatic tochopherol content in primary hepatocellular carcinoma and liver metastases. Hepatology, 26, p. 67.

Rosner M.H. and Bolton W.K., (2006):

Renal function testing. American Journal of Kidney Diseases, 47:174-183.

Sa'adah N., Nurhayati A. Ashuri N. and Purwani K., (2017):

Analysis of lipid profile and atherogenic index in hyperlipidemic rat (RattusnorvegicusBerkenhout, that given the methanolic extract of Parijoto (Medinillaspeciosa). n AIP Conference Proceedings , 1854(1):020031. 


\section{Egypt. J. of Nutrition and Health Vol. 15 No. 2 July (2020)}

Saldeen T., Li D. and Mehta J., (1999):

Differential effects of $\alpha$ - and $\gamma$-tocopherol on low-density lipoprotein oxidation, superoxide activity, platelet aggregation and arterial thrombogenesis. Journal of the American College of Cardiology,34:1208-1215.

Satoh K., (1978):

Serum lipid peroxide in cerebrovascular disorders de-termined by a new colorimetric method. Clinica Chimica Acta, 90, 37-43.

Sherwin J.E., (1984):

Liver function. In:Kaplan LA, Pesce AJ, eds. Clinical chemistry, theory, analysis, and correlation. St Louis: Mosby; 420- 438.

Sirato-Yasumoto N., Katsuta M. and Okuyama Y., (2001):

Effect of sesame seed rich in sesamin and sesamolin on fatty acid oxidation in rat liver. Journal of Agricultural and Food Chemistry, 49 (5), p. 2647.

Singh U., Kumar S. and Dhakal S., (2017):

Study of oxidative stress in hypercholesterolemia. International Journal of Contemporary Medical Research, 4, 1204-1207.

Smathers R.L., Galligan J.J., Stewart B.J. and Petersen D.R., (2011):

Overview of lipid peroxidation products and hepatic protein modification in alcoholic liver disease. Chemico-Biological Interactions, 192, 107-112.

Stevens L., Coresh J., Greene T. and Levey A., (2006):

Assessing kidney function--measured and estimated glomerular filtration rate. New England Journal of Medicine, 354: 2473-2483.

Takahashi M., Nishizaki Y., Sugimoto N. and et al., (2016):

"Determination and purification of sesamin and sesamolin in sesame seed oil unsaponified matter using reversed-phase liquid chromatography coupled with photodiode array and tandem mass spectrometry and high-speed countercurrent chromatography," Journal of Separation Science, vol. 39, no. 20, pp. 3898-3905, 2016.

Teklad Custom Diet, (2015):

Atherogenic Rodent Diet, TD. 02028. Envigo, (800)483-5523.

Tietz N.W., (1999):

Text book of clinical chemistry, 3rd edition. Burtis CA, Ashwood ER: WB Saunders Co.Clinical Chemistry, Volume 45, Issue 6, Pages 913-914.

Treasure J., (2003):

Urtica semen reduces serum creatinine levels. Journalof the American Herbalists Guildpromotes, 4:22-25. 


\section{Hoda S. Ibrahim, et al}

Walmsley S., Broeckling C., Hess A., Prenni J. and Curthoys N., (2010):

Proteomic analysis of brush-border membrane vesicles isolated from purified proximal convoluted tubules. American Journal of Physiology-Renal Physiology,298: F1323-F1331.

Weber D., Danielson K., Wright S. and Foley J., (2002):

Hematology and serum biochemistry values of dusky-footed wood rat (Neotomafuscipes). Journal of Wildlife Diseases,38: 576-582.

Wu W.H., Kang Y.P., Wang N.H., Jou H.J., and Wang T.A., (2006):

Sesame ingestion affects sex hormones, antioxidant status, and blood lipids in postmenopausal women; Journal of Nutrition, 136:1270 - 1275.

Wu M.S., Aquino L.B., Barbaza M.Y., Hsieh C.L., Cruz K.D., ang L.L. and Tsai P.W., (2019):

Anti-Inflammatory and Anticancer Properties of Bioactive Compounds from Sesamumindicum L.-A Review; Molecules, 24(24), 4426.

Yan C., Bravo E., Cantafora A., (1993):

Effect of taurine levels on liver lipid metabolism: an in vitro study in the rat. Proceedings of the Society for Experimental Biology and Medicine, 202, p. 88.

Yang R., Shi Y.,Hao G., Li W. and Le G., (2008):

Increasing oxidative stress with progressive hyperlipidemia in human: Relation between malondialdehyde and atherogenic index. Journal of Clinical Biochemistry and Nutrition, 43, 154-158.

Yushiro F., Ayumi U., Katsunori F., Makoto C., Makoto C., Takashi O. and Hiroshi M., (2018):

Chemical characterization and biological activity in young sesame leaves (Sesamumindicum L.) and changes in iridoid and polyphenol content at different growth stages. Publish with PLOS ONE, 10, 1371. 


\section{التاثيرات الحيوية لبذور السمسم ضد تصلب الثرايين والالتهابات في الجرذان هدى سلامة ابراهيم , لمياء على احمد و اسماء احمد محمد الملخص العربي}

تهدف هذه الدراسة الى معرفة النشاط المضاد للأكسدة للمعاملات المختلفة لبذور السمسم على تصلب الثر ايين

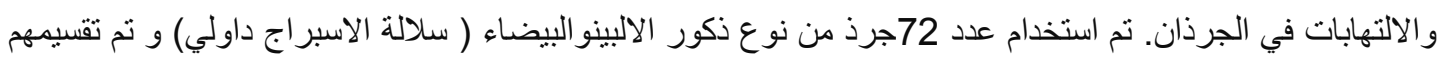

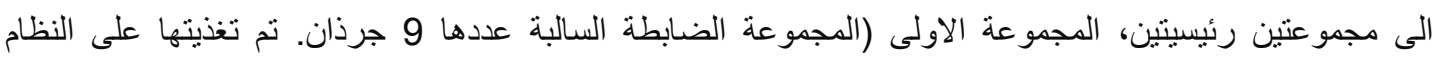

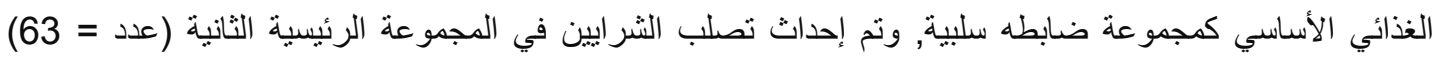

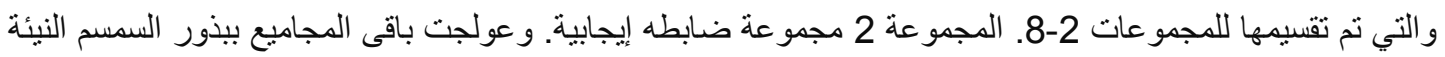
و الدحمصة والمتخمرة على مستويين من الاستهلاك (100 و150 جم / كجم غذاء). في نهاية فترة التجربة (8 أسابيع)

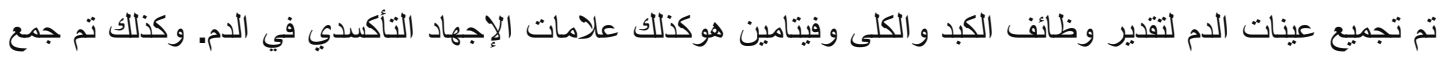
الأعضاء مثل الكبد والكلى من جميع الجرذان للاراسات النسيجية. ونم إحداث التهاب في مخلب الجرذان التصاب التصابة

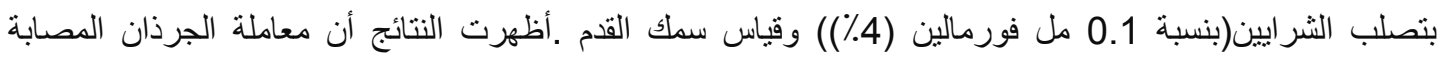
بتصلب الثرايين ببذور السمسم النيئة والمحمصة والمتخمرة على مستويين المستخدمين أدى إلى تحسن فى انزيمات

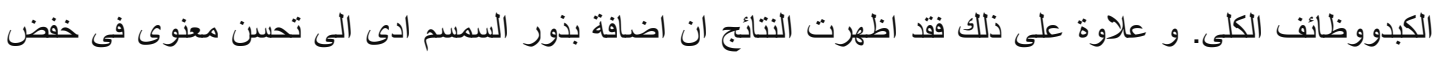

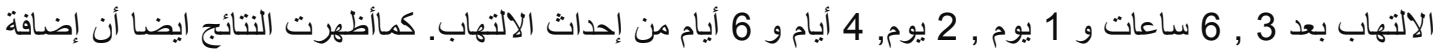

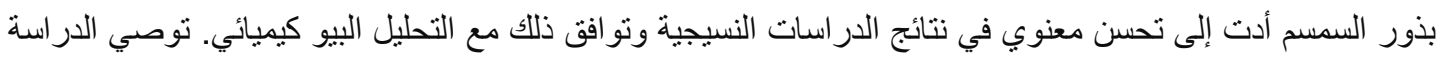
الحالية بزيادة استهلاك بذور السمسم بأثكال مختلفة عند المسنويات المختبرة لما له من تاثير ايجابى. وتشير الي الهي أهمية

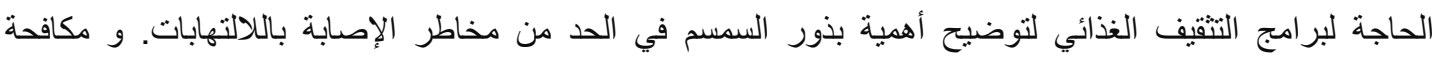

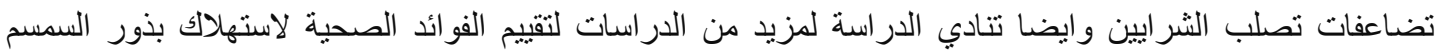
الكلمات المفتاحية: بذور السمسم النىء ـ السمسم المحمصـ فو ائد السمسم المتخمر ـ تصلب الثر ايين ـ- الفحص 